\title{
Penerapan Metode Fuzzy Tsukamoto dalam Sistem Pendukung Keputusan untuk Menentukan Jumlah Produksi Opak Gambir
}

\author{
Moh Bagus Sholikul Adib ${ }^{1, *}$, Abd. Charis Fauzan ${ }^{2}$, Naela Nur Choiriyah ${ }^{3}$, Ilham Kurniawan ${ }^{4}$ \\ Program Studi Ilmu Komputer, Universitas Nahdlatul Ulama Blitar, Indonesia \\ 12adibtheguns@gmail.com; ${ }^{2}$ abdcharis@ unublitar.ac.id; ${ }^{3}$ choiriyah030303@gmail.com \\ * corresponding author
}

INFO ARTIKEL

Sejarah Artikel

Diterima: 30 Oktober 2019

Direvisi: 5 Februari 2020

Diterbitkan: 30 April 2020

Kata Kunci

Fuzzy Tsukamoto

Sistem pendukung keputusan

Opak gambir

\section{ABSTRAK}

Penentuan jumlah produksi adalah salah satu proses pengambilan keputusan perusahaan yang sangat penting. Untuk menentukan berapa jumlah produksi pada bulan selanjutnya, bergantung pada berapa jumlah permintaan dan berapa jumlah persediaan dari bulan sebelumnya. Jumlah permintaan yang tidak sama di tiap periodenya menyebabkan ketidakpastian di dalam menentukan jumlah produksi perusahaan. Logika fuzzy adalah sistem keilmuan yang dipergunakan dalam menganalisis ketidakpastian. Penelitian ini mengaplikasikan logika fuzzy dengan metode fuzzy tsukamoto dalam menentukan jumlah produksi berdasar pada jumlah permintaan dan jumlah persediaan opak gambir. Terdapat 3 tahap dalam metode ini untuk mendapatkan hasil yaitu mendefinisikan variabel fuzzy, inferensi dan difuzzifikasi. Hasilnya, fuzzy tsukomoto dalam menentukan produksi opak gambir dinilai efektif untuk memperkirakan jumlah produksi sehingga kerugiaan bisa lebih ditekan.

\section{PENDAHULUAN}

Salah satu keberhasilan yang ingin di capai adalah bagaimana bisa mengeluarkan modal yang sekecil mungkin dan mendapatkan keuntungan yang sebesar mungkin [1]. Salah satunya dalam penentuan jumlah produsi barang haruslah tepat dalam memperkirakan karena jika tidak tepat menentukan jumlah produksi yang sesuai dengan jumlah persedian yang dan permintaan di pasar di khawatirkan akan menyebabkan low buget [2]. Hal ini tentunya sangat merugikan perusahaan. Oleh karena itu untu mengatasi persoalan di atas di sini kami akan menggunakan logika fuzzy dalam memperkirakan jumlah produksi berdasarkan jumlah permintaan dan persediaan. Diharapkan dengan logika fuzzy dapat membantuperusahaan untuk memperkirakan jumlah barang yang akan di produksi.

Teori tentang fuzzy set atau logika samar pertama kali dikemukaan oleh Lotfi Zadeh sekitar tahun 1965 pada sebuah makalah yang berjudul ' fuzzy sets'. Setelah itu, sejak pertengahan 1970-an, para peneliti jepang berhasil mengaplikasikan teori ini dalam berbagai permasalah praktis. Pada penelitian sebelumnya [2] telah di teliti cara menentukan jumlah produksi berdasarkan jumlah penerapan metode fuzzy tsukamoto untuk menentukan jumlah jam overtime pada produksi barang, terdapat pula implementasi fuzzy tsukamoto untuk menentukan produksi jenang kudus [3]. Kemudian, implementasi logika fuzzy tsukamoto dalam menentukan produksi tahu [5]. Dari penelitian tersebut, peneliti mengembangkan sistem pendukung keputusan dengan penentuan berapa jumlah produksi didasarkan dari jumlah permintaan dan jumlah persediaan untuk produksi opak gambir menggunakan fuzzy tsukamoto. Melalui, metode ini, sistem diharapkan dapat memperkirakan dan memutuskan 
jumlah produksi opak gambir, sehingga efektif untuk meningkatkan keuntungan usaha kecil menengah (UKM).

\section{METODE}

Untuk metode penelitian yang diterapkan oleh peneliti menggunakan metode pengumpulan data secara sintesis, dan wawancara dengan salah satu pemilik usaha UKM opak gambir. Kemudian untuk metode yang dipakai dalam teknik pengolahan data menggunakan aplikasi Ms Excel. Adapun data yang kami buat adalah pada produksi opak gambir dalam periode 12 bulan menggunakan variabel permintaan, persediaan dan produksi, ditunjukkan oleh Tabel 1.

Tabel 1. Jumlah permintaan, persediaan dan produksi selama 12 bulan

\begin{tabular}{|l|c|c|c|}
\hline \multicolumn{1}{|c|}{ Bulan } & Permintaan & Persediaan & Jumlah Produksi \\
\hline Januari & 2000 & 300 & 3000 \\
\hline Februari & 2300 & 200 & 3500 \\
\hline Maret & 2700 & 100 & 5000 \\
\hline April & 2600 & 500 & 3400 \\
\hline Mei & 3000 & 500 & 6000 \\
\hline Juni & 3050 & 550 & 4500 \\
\hline Juli & 4000 & 430 & 5500 \\
\hline Agustus & 5500 & 230 & 3400 \\
\hline September & 4500 & 120 & 3000 \\
\hline Oktober & 3000 & 300 & 4000 \\
\hline Nopember & 2300 & 400 & 5000 \\
\hline Desember & 2500 & 600 & 6000 \\
\hline
\end{tabular}

Untuk menentukan berapa banyak jumlah produksi opak gambir, terdapat 3 proses yang dilakukan [4][5] yaitu : 1). Fuzzyfication : merubah nilai input kedalam fuzzy input yang ditentukan berdasarkan fungsi keanggotaan tertentu; 2) Inference: penalaran menggunakan Fuzzy input dan Fuzzy rules yang telah ditentukan dan menghasilkan Fuzzy output. 3). Defazzyfication : mengubah fuzzy output menjadi nilai crisp berdasarkan fungsi keanggotaan untuk output. Untuk menyelesaikan permasalah pada produksi opak gambir ini maka metode yang kami gunakan untu menyelesaikan permasalahan di atas menggunakan logia fuzzy model Tsukamoto. Variabel yang dipakai untuk memprediksi jumlah produksi opak gambir menggunakan Fuzzy Tsukamoto yaitu persediaan, permintaan, produksi.

\section{Fuzzifikasi}

Masukan-masukkan yang bernilai kebenaran pasti dikonversikan ke dalam bentuk fuzzy input berupa nilai linguistik dan dittentikan berdasarkan fungsi keanggotaan. Pada kasus di atas nilai linguistik yang di gunakan untuk variabel persediaan yaitu turun dan dan naik,kemudian untuk permintaan sediit dan banyak sedangan untuk produsi yaitu berkurang dan bertambah.

1. Variabel Permintaan. Dari data yang kami buat di katakan TURUN apabila jumlah permintaan $<=2000$ dan NAIK apabila jumlah permintaan $\geq 5500$. Permintaan terdiri dari 2 himpunan fuzzy yaitu TRUN dan NAIK. Ditunjukkan sebagaimana Gambar 1, 2 dan 3. 


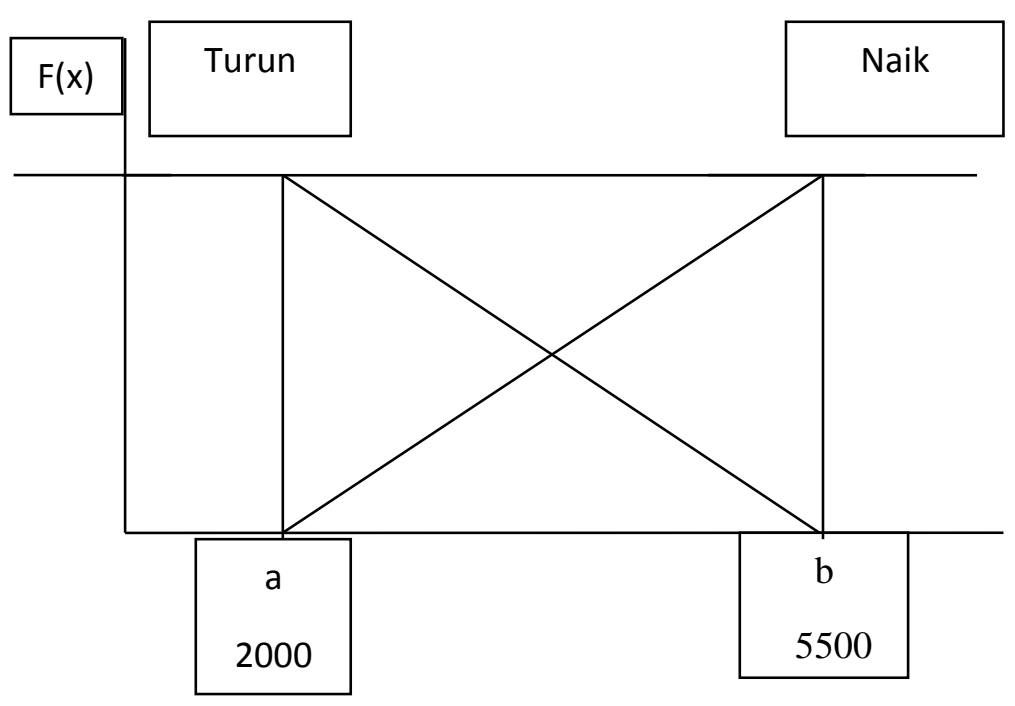

Gambar 1. Grafik dan notasi matematika dari fungsi keanggotaan bahu pada variabel permintaan.
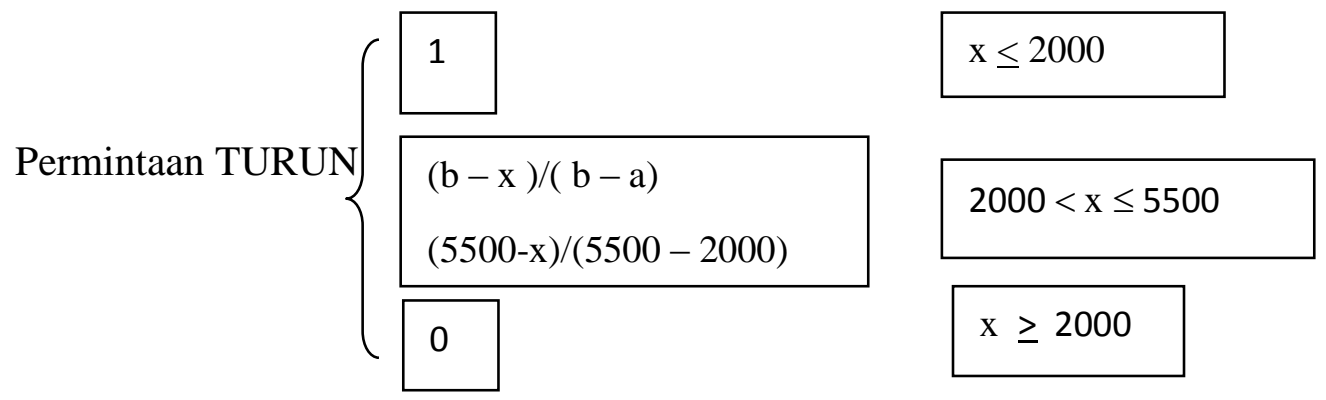

Gambar 2. Rumus permintaan turun pada variabel permintaan

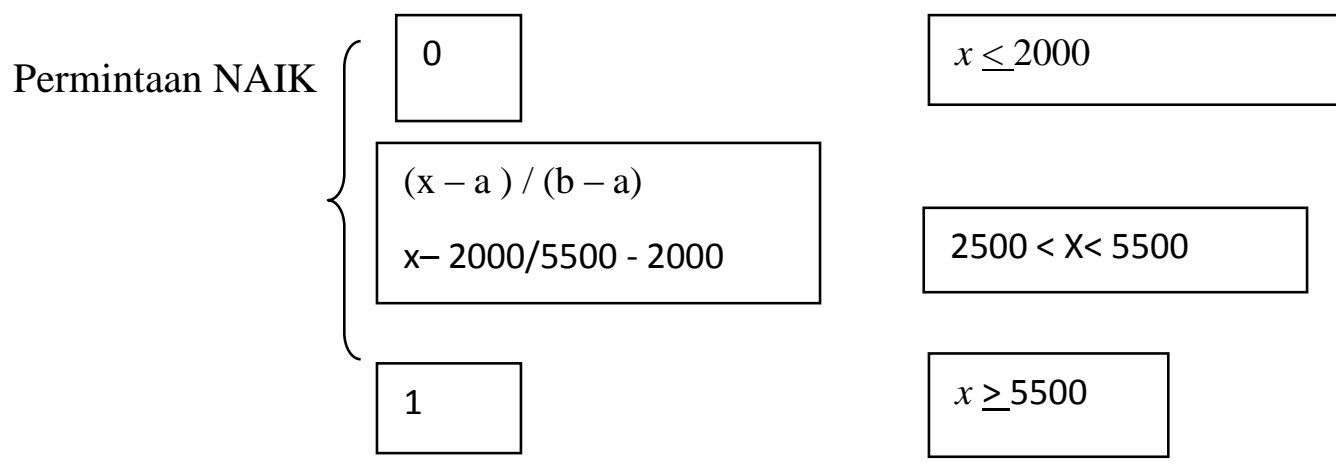

Gambar 3. Rumus permintaan naik pada variabel permintaan

2. Variabel Persediaan. Dari data yang kami buat di katakan TURUN apabila jumlah persediaan $<=100$ dan NAIK apabila jumlah persediaan $\geq 600$. Variabel permintaan terbagi menjadi 2 variabel linguistik SEDIKIT dan BANYAK. Variabel linguistik SEDIKIT dan BANYAK menggunakan grafik fungsi keanggotaan berbentu bahu. Ditunjukkan sebagaimana Gambar 4, 5 dan 6. 


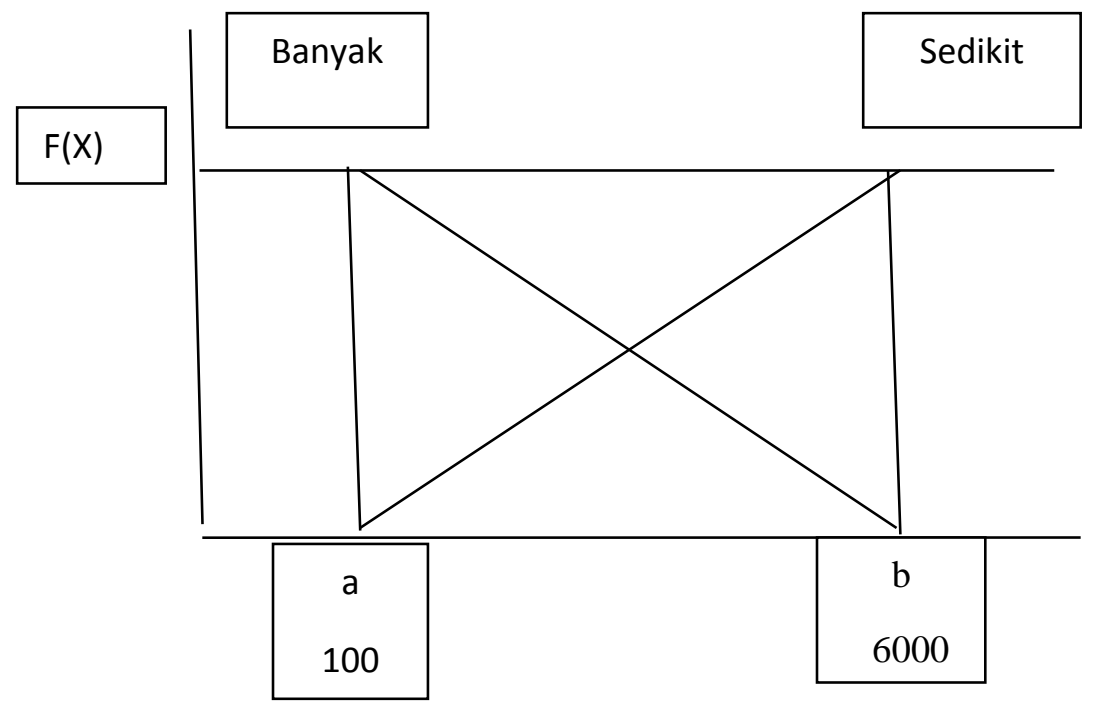

Gambar 4. Grafik dan notasi matematika dari fungsi keanggotaan bahu pada variabel persediaan.

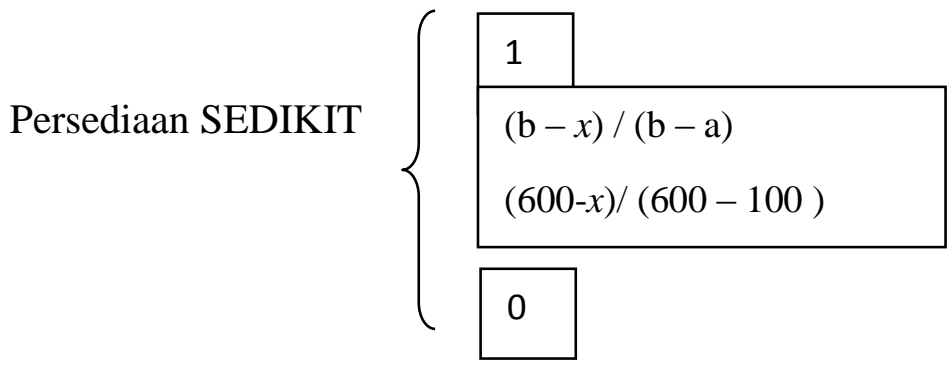

Gambar 5. Rumus persediaan sedikit pada variabel persediaan

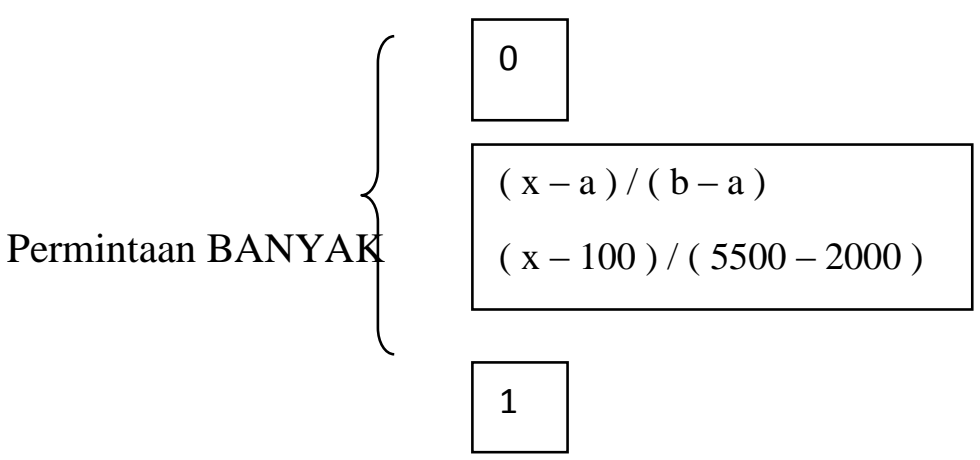

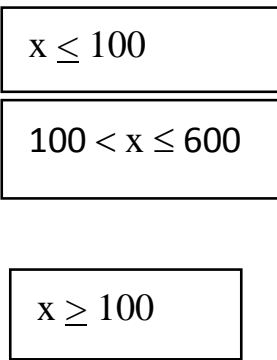

$$
X \leq 100
$$

$2000<x \leq 5500$

$X \geq 600$

Gambar 6. Rumus persediaan banyak pada variabel persediaan

3. Variabel Produksi. Dari data yang kami buat di katakan TURUN apabila jumlah peroduksi $<=3000$ dan NAIK apabila jumlah peroduksi $\geq 6000$, kriteria persediaan dibagi dalam 2 himpunan fuzzy yaitu BERKURANG dan BERTAMBAH. Variabel permintaan dibagi dalam 2 variabel yaitu linguistik yaitu BERURANG dan BERTAMBAH . Variabel linguistik BERKURANG dan BERTAMBAH menggunakan grafik fungsi keanggotaan berbentu bahu. Ditunjukkan sebagaimana Gambar 7, 8 dan 9. 


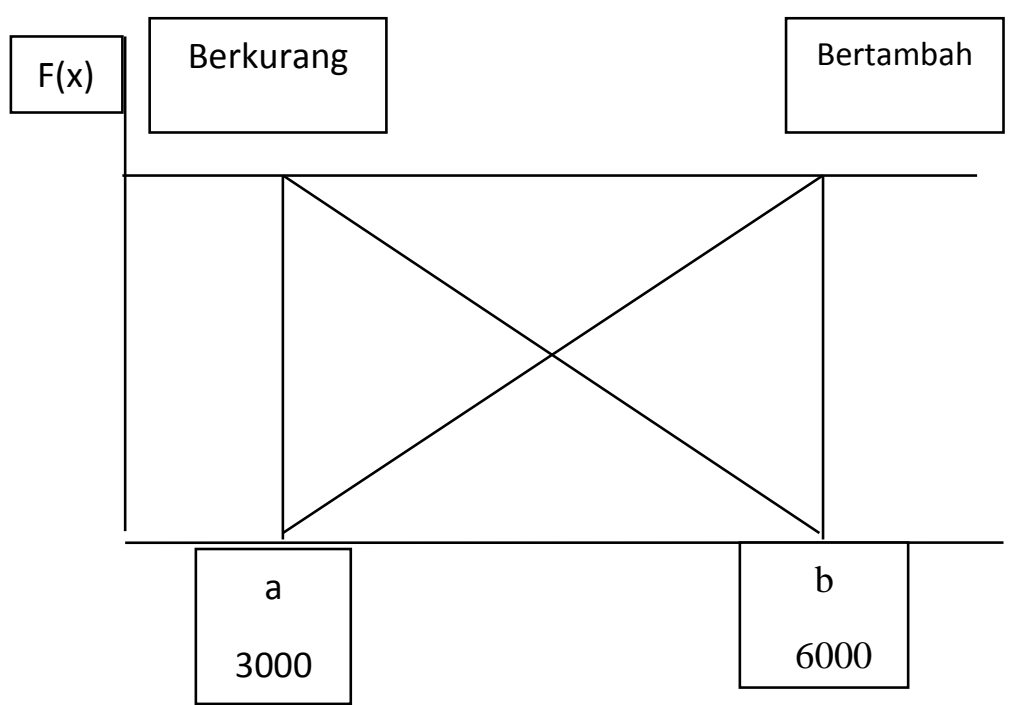

Gambar 7. Grafik dan notasi matematika dari fungsi keanggotaan bahu pada variabel produksi.

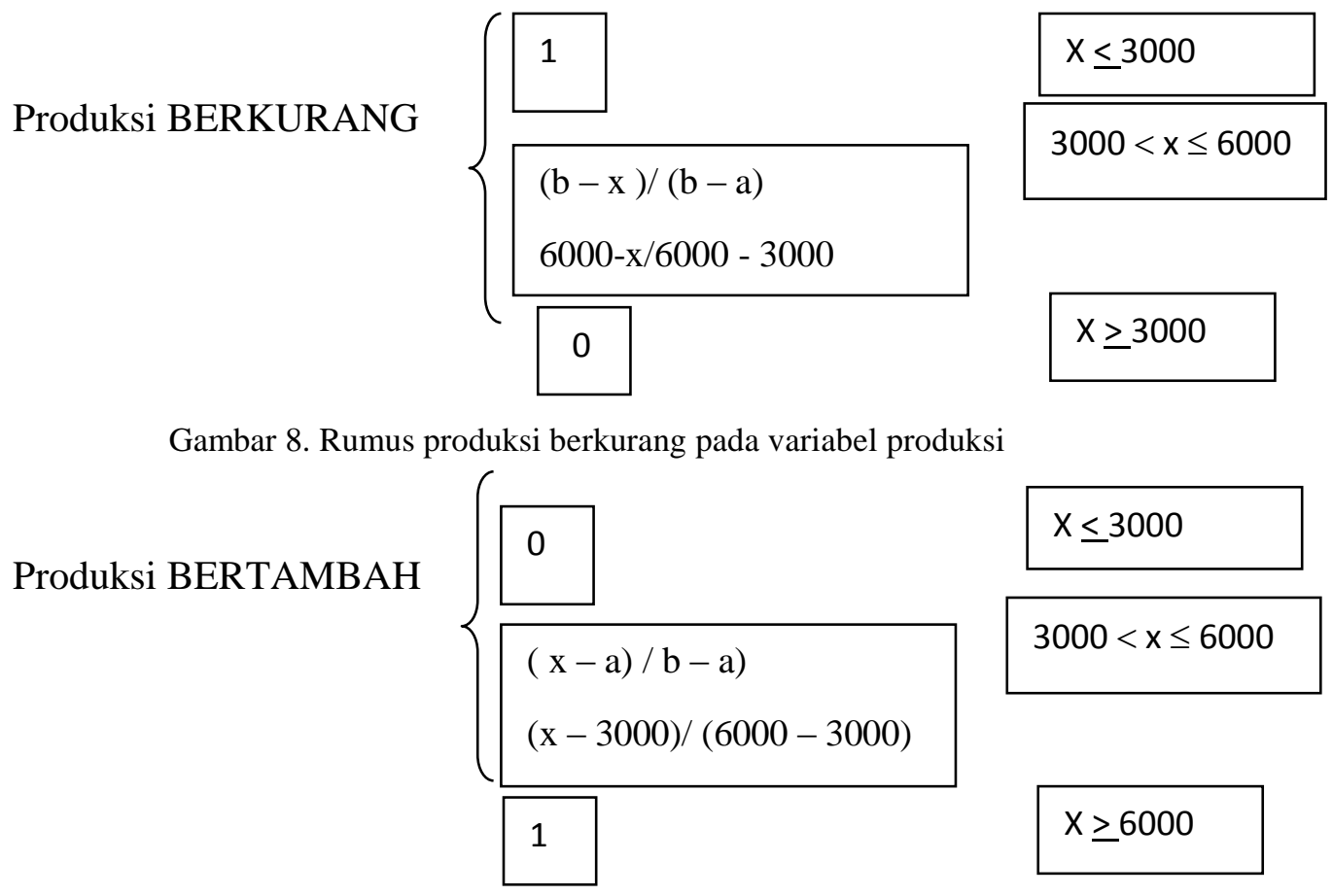

Gambar 9. Rumus produksi bertambah pada variabel produksi

Dari ketiga notasi matematika di atas akan digunakan untuk menghitung Logika Fuzzy pada proses inferensi.

\section{Inferensi}

Pada metode Tsukamoto di setiap konsekuenyang memiliki aturan Jika-Maka, harus dipresentasikan dengan himpunan fuzzy dengan fungsi keanggotaan [6]. Hasilnya output inferensi tiap aturan diberikan crips berdasarkan fire stength sebagaimana Tabel 2.

Tabel 2. Tiap aturan untuk proses inferensi

\begin{tabular}{|l|c|c|c|}
\hline Rule & Permintaan & Persediaan & Produksi \\
\hline R1 & Turun & Banyak & Berkurang \\
\hline
\end{tabular}




\begin{tabular}{|l|l|l|l|}
\hline R2 & Turun & Seikit & Berkurang \\
\hline R3 & Naik & Banyak & Bertambah \\
\hline R4 & Naik & Sedikit & Bertambah \\
\hline
\end{tabular}

Dengan deinisi aturan fuzzy pada gambar 3.1diatas, kita mempunyai 4 x $3=12$ aturan fuzzy yaitu:

IF Permintaan $=$ Turun AND Persediaan $=$ Banyak THEN Produksi Berkurang

IF Permintaan Naik AND Persediaan $=$ sedikit THEN Produksi $=$ Bertambah

\section{Deffuzifikasi}

Ada banyak metode Defuzzyfikasiyang dipublikasikan dalam berbagai masalah diantaranya: centroid metode, heigh metode, first (or last) of maxima, mean max motode dan weighted average [7]. . Untuk rums yang aan peneliti gunaan untuk menyelesaikan maslah produsi ada opak gambir yaitu menggunakan merode weighted average. Pada metode ini nilai rata-rata diambil berdasarkan derajat keanggotaan yang berbobot, sehingga $\mathrm{y}^{*}$ didefinisikan sebagai:

$$
\mathrm{y}^{*}=\sum_{\mu(y)}^{\mu(y) y}
$$

Dimana y adalah nilai crisp dan $\mu(\mathrm{y})$ adalah derajat keanggotaan dari crisp y.

\section{HASIL DAN PEMBAHASAN}

Pada metode Tsukamoto di setiap konsekuen yang memiliki aturan Jika - Maka, harus dipresentasikan dengan himpunan fuzzy dengan fungsi keanggotaan yang monoton. Hasilnya output inferensi di setiap aturan diberikan crisp berdasarkan predikat. Hasilnya diperoleh dengan rata-rata terbobot.

Tabel 3. Jumlah permintaan, persediann dan produksi selama 12 bulan

\begin{tabular}{|l|c|c|c|}
\hline \multicolumn{1}{|c|}{ Bulan } & Permintaan & Persediaan & Jumlah Produksi \\
\hline Januari & 2000 & 300 & 3000 \\
\hline Februari & 2300 & 200 & 3500 \\
\hline Maret & 2700 & 100 & 5000 \\
\hline April & 2600 & 500 & 3400 \\
\hline Mei & 3000 & 500 & 6000 \\
\hline Juni & 3050 & 550 & 4500 \\
\hline Juli & 4000 & 430 & 5500 \\
\hline Agustus & 5500 & 230 & 3400 \\
\hline September & 4500 & 120 & 3000 \\
\hline Oktober & 3000 & 300 & 4000 \\
\hline Nopember & 2300 & 400 & 5000 \\
\hline Desember & 2500 & 600 & 6000 \\
\hline
\end{tabular}

Perusahaan opak gambir memproduksi opak gambir mulai januari sampai desember. Dari data 1 tahun itu permintaan terbesar mencapai 5500 bungus opak/bulan, dan permintaan terkecil mencapai 2000 bungkus opak/bulan. Persediaan opak digudang terbanyak mencapai 600 bungkus opak/bulan, dan persediaan opak digudang tersedikit mencapai 100 bungkus opak/bulan. Berapa opak yang diproduksi, jika permintaan sebanyak 2600 bungkus opak dan 
persediaan digudang 440 bungus opak? Dari pernyataan diatas kami membuat 4 aturan untuk menyelesaikan pertanyaan tersebut, yang disimbolkan rengan RI,R2,R3, dan R4 yang ditunjukkan oleh Gambar 10.

\begin{tabular}{|l|c|}
\hline Jumlah Produksi Jika Permintaan $=2600$ dan persediaan $=440$ & ??? \\
\hline R1 $=$ JIKA PERMINTAAN TURUN DAN PERSEDIAAN BANYAK MAKA PRODUKSI BERKURANG \\
\hline R2 = JIKA PERMINTAAN TURUN DAN PERSEDIAAN SEDIKIT MAKA PRODUKSI BERKURANG \\
\hline R3 = JIKA PERMINTAAN NAIK DAN PERSEDIAAN BANYAK MAKA PRODUKSI BERTAMBAH \\
\hline R4 = JIKA PERMINTAAN NAIK DAN PERSEDIAAN SEDIKIT MAKA PRODUKSI BERTAMBAH \\
\hline
\end{tabular}

Gambar 10. Empat aturan penyelesaian

Terdapat 3 Variabel fuzzy yang dimodelkan yaitu :

Permintaan terdiri atas 2 himpunan fuzzy yaitu NAIK dan TURUN

$\begin{array}{ll}\checkmark & \text { PrmTURUN }=\mathrm{b}-\mathrm{x} / \mathrm{b}-\mathrm{a}=5500-2600 / 5500-3500=2900 / 3500=0,83 \\ \checkmark & \text { PrmNAIK }=\mathrm{x}-\mathrm{a} / \mathrm{b}-\mathrm{a}=2600-2000 / 5500-2000=600 / 3500=0,17\end{array}$

\begin{tabular}{|c|c|c|c|c|c|}
\hline \multirow{2}{*}{ Permintaan } & Batas Kiri & Batas kanan & & & \\
\hline & 2000 & 5500 & & & \\
\hline Linier & Rumus & b & $x$ & Jumlah & Hasil \\
\hline \multirow{2}{*}{ Turun } & $b-x$ & 5500 & 2600 & 2900 & \multirow{2}{*}{0,83} \\
\hline & $b-a$ & 5500 & 2000 & 3500 & \\
\hline Linier & Rumus & $x$ & a & Jumlah & Hasil \\
\hline \multirow{2}{*}{ Naik } & $x-a$ & 2600 & 2000 & 600 & \multirow{2}{*}{0,17} \\
\hline & b-a & 5500 & 2000 & 3500 & \\
\hline
\end{tabular}

Gambar 11. Rumus permintaan

Keterangan:

$\mathrm{b}=$ nilai terbesar dari permintaan

$\mathrm{a}=$ nilai terkecil dari permintaan

$\mathrm{x}=$ jumlah permintaan

Persediaan terdiri atas 2 himpunan fuzzy yaitu BANYAK dan SEDIKIT

$\begin{array}{ll}\checkmark & \text { PsdSEDIKIT }=\mathrm{b}-\mathrm{x} / \mathrm{b}-\mathrm{a}=600-440 / 600-100=160 / 500=0,32 \\ \checkmark & \text { PsdBANYAK }=\mathrm{x}-\mathrm{a} / \mathrm{b}-\mathrm{a}=440-100 / 600-100=340 / 500=0,68\end{array}$

\begin{tabular}{|c|c|c|c|c|c|}
\hline \multirow{2}{*}{ Persediaan } & Batas Kiri & Batas Kanan & & & \\
\hline & 100 & 600 & & & \\
\hline Linier & Rumus & b & $x$ & Jumlah & Hasil \\
\hline \multirow{2}{*}{ Sedikit } & b-x & 600 & 440 & 160 & \multirow{2}{*}{0,32} \\
\hline & b-a & 600 & 100 & 500 & \\
\hline Linier & Rumus & $x$ & a & Jumlah & Hasil \\
\hline \multirow{2}{*}{ Banyak } & $\mathbf{x}-\mathbf{a}$ & 440 & 100 & 340 & \multirow{2}{*}{0,68} \\
\hline & b-a & 600 & 100 & 500 & \\
\hline
\end{tabular}

Gambar 12. Rumus persediaan 
Keterangan:

$\mathrm{b}=$ nilai terbesar dari persediaan

$\mathrm{a}=$ nilai terkecil dari persediaan

$\mathrm{x}=$ jumlah persediaan

Produksi, terdiri dari 2 himpunan fuzzy yaitu BERKURANG dan BERTAMBAH

$\checkmark$ PdkKURANG $=\mathrm{b}-\mathrm{x} / \mathrm{b}-\mathrm{a}=6000-\mathrm{x} / 6000-3000=6000-\mathrm{x} / 3000$

$\checkmark$ PdkTAMBAH $=\mathrm{x}-\mathrm{a} / \mathrm{b}-\mathrm{a}=\mathrm{x}-3000 / 6000-3000=\mathrm{x}-3000 / 3000$

\begin{tabular}{|c|c|c|c|c|}
\hline \multirow{2}{*}{ Produksi } & Batas Kiri & Batas Kanan & & \\
\hline & 3000 & 6000 & & \\
\hline Linier & Rumus & $b$ & $x$ & Jumlah \\
\hline \multirow{2}{*}{ Kurang } & b-x & 6000 & $\mathrm{x}$ & $6000-x$ \\
\hline & b-a & 6000 & 3000 & 3000 \\
\hline Linier & Rumus & $x$ & $a$ & Jumlah \\
\hline \multirow{2}{*}{ Tambah } & $x-a$ & $\mathrm{x}$ & 3000 & $x-3000$ \\
\hline & b-a & 6000 & 3000 & 3000 \\
\hline
\end{tabular}

Gambar 13. Rumus produksi

Keterangan:

$\mathrm{b}=$ nilai terbesar dari produksi

$\mathrm{a}=$ nilai terkecil dari produksi

$\mathrm{x}=$ jumlah produksi

kemudian kita mencari nilai x pada setiap aturan dengan cara menggunakan fungsi MIN pada aplikasi fungsi implikasinya.

R1=Jika PERMINTAAN TURUN dan PERSEDIAAN BANYAK maka jumlah PRODUKSI BERKURANG

$\checkmark \operatorname{PrmTURUN} \min (0,83), \operatorname{PsdBANYAK} \min (0,68)$. Min $=(0,68)$

$\checkmark \quad \mathrm{X} 1=\mathrm{b}-\mathrm{x} / \mathrm{b}-\mathrm{a}=6000-\mathrm{x} / 3000=0,68$

$$
\begin{aligned}
= & 6000-x=0,68 \times 3000 \\
= & 6000-x=2040 \\
& 6000-2040=x \\
x= & 3960
\end{aligned}
$$

R1 = JIKA PERMINTAAN TURUN DAN PERSEDIAAN BANYAK MAKA JUMLAH PRODUKSI BERKURANG

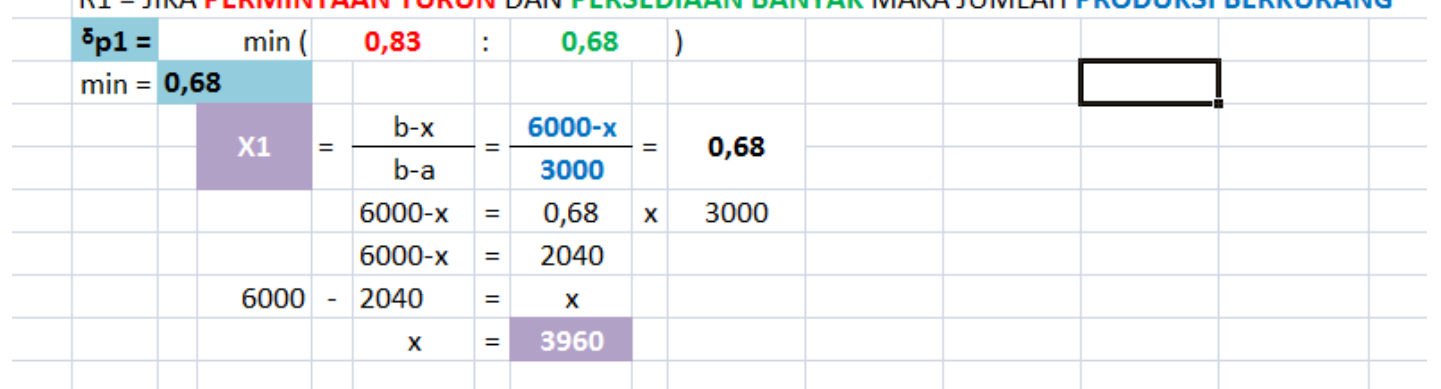

Gambar 14. Rumus mencari R1 
Keterangan:

$\mathrm{b}=$ nilai terbesar dari produksi

$\mathrm{a}=$ nilai terkecil dari produksi

$\mathrm{x}=$ jumlah produksi

R2=Jika PERMINTAAN TURUN dan PERSEDIAAN SEDIKIT maka jumlah PRODUKSI BERKURANG

$\checkmark \operatorname{PrmTURUN} \min (0,83)$, PsdSEDIKIT $\min (0,32)$. Min $=(0,32)$

$\checkmark \quad \mathrm{X} 2=\mathrm{b}-\mathrm{x} / \mathrm{b}-\mathrm{a}=6000-\mathrm{x} / 3000=0,32$

$=6000-\mathrm{x}=0,32 \times 3000$

$=6000-\mathrm{x}=960$

$6000-960=x$

$\mathrm{x}=5040$

R2 = JIKA PERMINTAAN TURUN DAN PERSEDIAAN SEDIKIT MAKA JUMLAH PRODUKSI BERKURANG

${ }^{8} \mathbf{p} 2=\min (0,83: 0,32)$

$\min =0,32$

$\times 2$

$\frac{b-x}{b-a}=\frac{6000-x}{3000}=0,32$

$6000-x=0,32 \times 3000$

$6000-x=960$

$6000-960$

$\begin{array}{cc}= & \mathrm{x} \\ = & 5040\end{array}$

Gambar 15. Rumus mancari R2

Keterangan:

$\mathrm{b}=$ nilai terbesar dari produksi

$\mathrm{a}=$ nilai terkecil dari produksi

$\mathrm{x}=$ jumlah produksi

R3=Jika PERMINTAAN NAIK dan PERSEDIAAN BANYAK maka jumlah PRODUKSI BERTAMBAH

$\checkmark$ PrmNAIK min $(0,83)$, PsdBANYAK $\min (0,17) \cdot \min =(0,17)$

$\checkmark \quad \mathrm{X} 3=\mathrm{x}-\mathrm{a} / \mathrm{b}-\mathrm{a}=\mathrm{x}-3000 / 3000=0,17$

$$
\begin{aligned}
& =x-3000=0,17 \times 3000 \\
& =x-3000=514,29 \\
& x=514,29+3000 \\
& x=3514,3
\end{aligned}
$$

R3 = JIKA PERMINTAAN NAIK DAN PERSEDIAAN BANYAK MAKA JUMLAH PRODUKSI BERTAMBAH

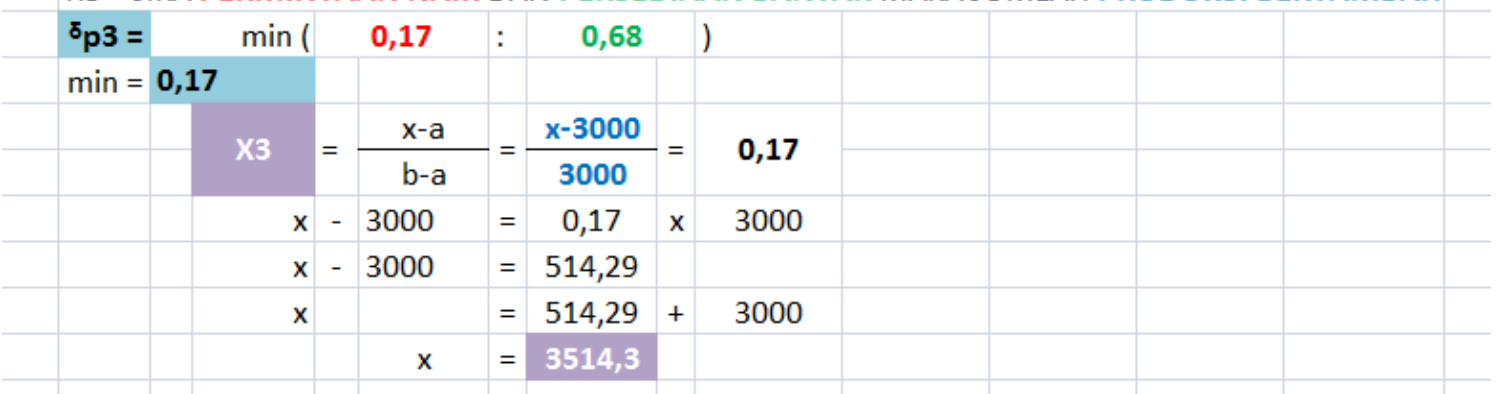

Gambar 16. Rumus mencari R3 
Keterangan:

$\mathrm{b}=$ nilai terbesar dari produksi

$\mathrm{a}=$ nilai terkecil dari produksi

$\mathrm{x}=$ jumlah produksi

R4 = Jika PERMINTAAN NAIK dan PERSEDIAAN SEDIKIT maka jumlah PRODUKSI BERTAMBAH

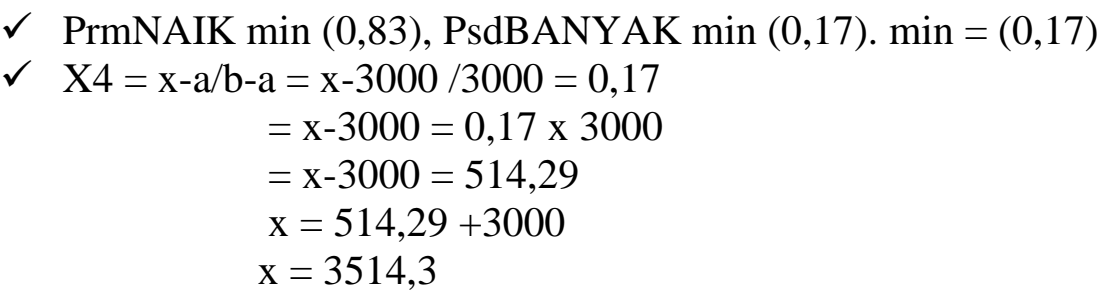

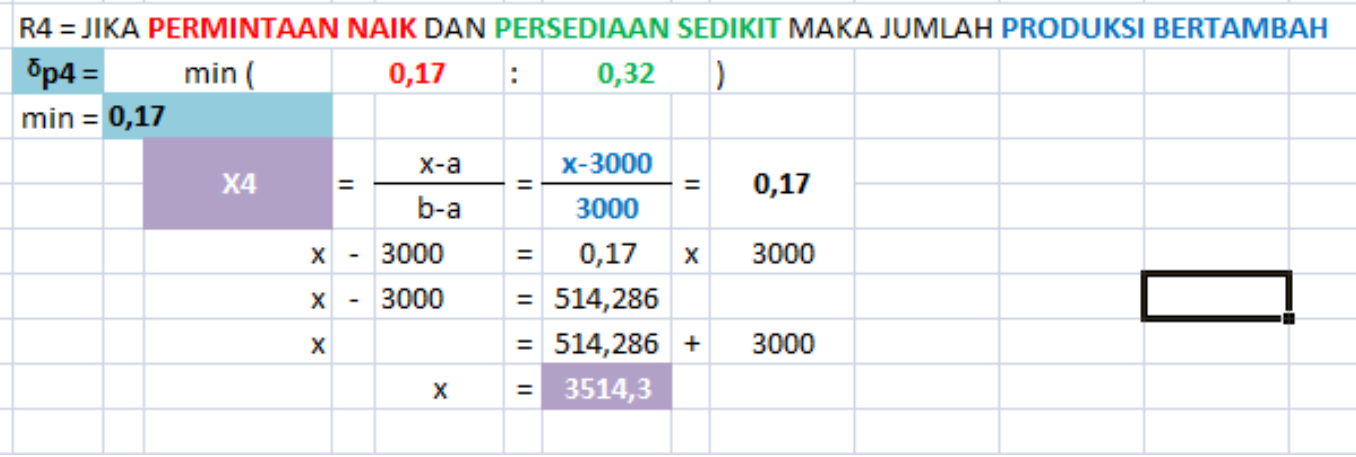

Gambar 17. Rumus mencari R4

Keterangan:

$\mathrm{b}=$ nilai terbesar dari produksi

$\mathrm{a}=$ nilai terkecil dari produksi

$\mathrm{x}=$ jumlah produksi

Nilai $X$ dapat dicari dengan cara berikut:

$$
\begin{aligned}
\checkmark \quad \mathrm{X} & =\left({ }^{\delta} \mathrm{p} 1 . \mathrm{x} 1\right)+\left({ }^{\delta} \mathrm{p} 2 \cdot \mathrm{x} 2\right)+\left({ }^{\delta} \mathrm{p} 3 \cdot \mathrm{x} 3\right)+\left({ }^{\delta} \mathrm{p} 4 \cdot \mathrm{x} 4\right) /{ }^{\delta} \mathrm{p} 1+{ }^{\delta} \mathrm{p} 2+{ }^{\delta} \mathrm{p} 3+{ }^{\delta} \mathrm{p} 4 \\
& =269,8+1612,8+602,45+602,449 / 1,68+0,32+0,17+0,17 \\
& =5510,5 / 1,3429 \\
& =4104
\end{aligned}
$$

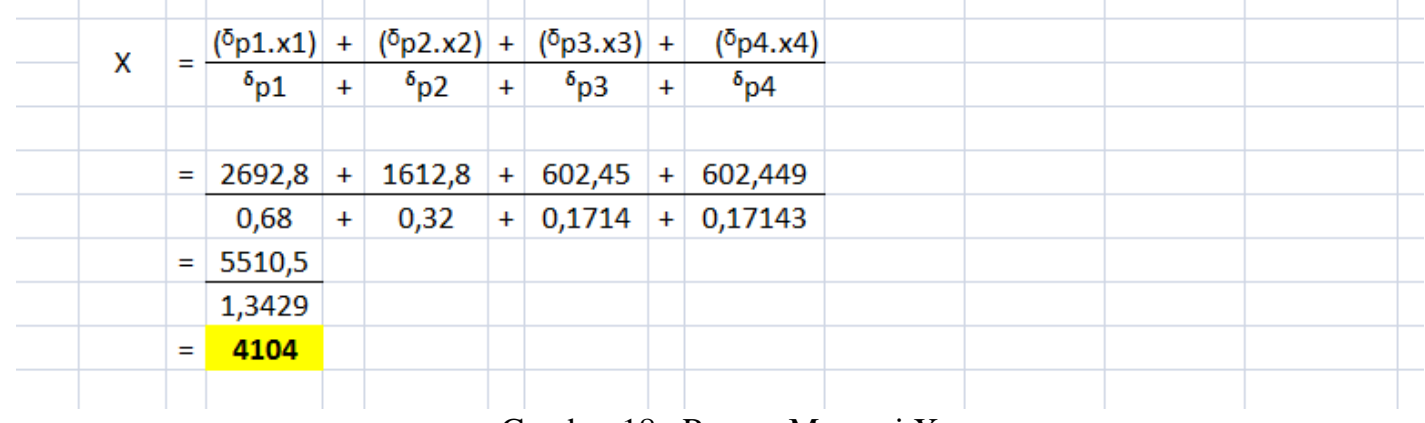

Gambar 18. Rumus Mencari X 


\section{KESIMPULAN}

Berdasarkan pembahasan diatas, pengimplementasian algoritma Fuzzy Tsukamoto dalam menentukan jumlah produksi opak gambir dapat dilakukan. Disimpulkan bahwa penentuan jumlah produksi opak gambir menggunakan Metode Fuzzy Tsukamoto dengan 3 variabel sebagai input antara lain: persediaan barang, permintaan dan output lebih efektif dibandingkan sistem saat ini yang menghitung manual. Karena dalam Metode Tsukamoto diperlukan tahapan yang spesifik untuk mendapat hasil, antara lain: 1) fuzzifikasi (penentuan variabel); rule; defuzzifikasi. Dengan mengimplementasikan Metode Fuzzy Tsukamoto untuk menentukan berapa jumlah produksi Opak Gambir berdasarkan pada jumlah permintaan dan jumlah persediaan, cara ini dinilai efektif untuk memperkirakan jumlah produksi sehingga kerugiaan bisa lebih ditekan.

\section{REFERENSI}

[1] Wibowo, I. C., Fauzan, A. C., Yustiana, M. D. P., \& Qhabib, F. A. (2019). Komparasi Algoritma Naive Bayes dan Decision Tree Untuk Memprediksi Lama Studi Mahasiswa. ILKOMNIKA: Journal of Computer Science and Applied Informatics, 1(2), 65-74.

[2] Setiawan, I., \& Sinaga, B. (2018). SISTEM PENDUKUNG KEPTUTUSAN PENENTUAN JUMLAH PRODUKSI SIMAS MARGARINE DENGAN MENERAPKAN METODE TSUKAMOTO PADA PT. SALIM IVOMAS PRATAMA Tbk. Journal Of Informatic Pelita Nusantara, 3(2).

[3] Azmi, T. U., Haryanto, H., \& Sutojo, T. (2018). Prediksi Jumlah Produksi Jenang di PT Menara Jenang Kudus Menggunakan Metode Logika Fuzzy Tsukamoto. Sisfotenika, 8(1), 23-34.

[4] Rahayu, A. E., Hikmah, K., Yustia, N., \& Fauzan, A. C. (2019). Penerapan K-Means Clustering Untuk Penentuan Klasterisasi Beasiswa Bidikmisi Mahasiswa. ILKOMNIKA: Journal of Computer Science and Applied Informatics, 1(2), 82-86.

[5] Nurmuslimah, N. S., \& Sriwijaya, H. (2018, September). SISTEM PENDUKUNG KEPUTUSAN PENENTUAN JUMLAH PRODUKSI TAHU MENGGUNAKAN METODE FUZZY TSUKAMOTO. In Prosiding Seminar Nasional Sains dan Teknologi Terapan (pp. 425-432).

[6] Wiguna, R. Y., \& Haryanto, H. (2015). Sistem berbasis aturan menggunakan logika fuzzy tsukamoto untuk prediksi jumlah produksi roti pada CV. gendis bakery. Skripsi. Fakultas Ilmu Komputer, Universitas Dian Nuswantoro, Semarang.

[7] Zadeh, L. A. (1988). Fuzzy logic. Computer, 21(4), 83-93. 